\title{
Virtuous organization: A structural equation modeling approach
}

\author{
Majid Zamahani, Ali Akbar Ahmadi, Mohammad Ali Sarlak and Hamideh Shekari*
}

Department of Public Administration, Payame Noor University, Tehran, I. R. of Iran

\begin{tabular}{|c|c|}
\hline C H R O N I C L E & A B S T RACT \\
\hline $\begin{array}{l}\text { Article history: } \\
\text { Received October 5, } 2012 \\
\text { Received in revised format } \\
30 \text { November } 2012 \\
\text { Accepted } 30 \text { November } 2012 \\
\text { Available online } \\
\text { December } 42012 \\
\text { Keywords: } \\
\text { Virtues in Organization } \\
\text { Virtuous Organization } \\
\text { Structural Equation Modeling } \\
\text { Path Analysis }\end{array}$ & $\begin{array}{l}\text { For years, the idea of virtue was unfavorable among researchers and virtues were traditionally } \\
\text { considered as culture-specific, relativistic and they were supposed to be associated with social } \\
\text { conservatism, religious or moral dogmatism, and scientific irrelevance. Virtue and virtuousness } \\
\text { have been recently considered seriously among organizational researchers. The proposed study } \\
\text { of this paper examines the relationships between leadership, organizational culture, human } \\
\text { resource, structure and processes, care for community and virtuous organization. Structural } \\
\text { equation modeling is employed to investigate the effects of each variable on other components. } \\
\text { The data used in this study consists of questionnaire responses from employees in Payam e } \\
\text { Noor University in Yazd province. A total of } 250 \text { questionnaires were sent out and a total of } \\
211 \text { valid responses were received. Our results have revealed that all the five variables have } \\
\text { positive and significant impacts on virtuous organization. Among the five variables, } \\
\text { organizational culture has the most direct impact }(0.80) \text { and human resource has the most total } \\
\text { impact }(0.844) \text { on virtuous organization. }\end{array}$ \\
\hline
\end{tabular}

\section{Introduction}

A review of scholarly literature associated with the concept of virtuousness discloses that little agreement exists regarding its definition and attributes (Cameron \& Winn, 2012). The term virtue is associated with singular attributes, which represents moral excellence. Based on the Latin word virtus, or the Greek aréte, a virtue is not a product of social convention but is a basic element of the human circumstances (Cameron, 2011). Virtuousness also differs from the idea of ethics and a dominant emphasis in the ethics literature is to prevent harm, fulfilling contracts, ensuring compliance, and obeying rules and regulations. Practically, ethics are recognized and implemented as duties (Cameron, 2011) but virtuousness is going beyond ethics. Virtuousness is the best of the human condition, the most ennobling behaviors and outcomes, the excellence and essence of humankind (Comte-Sponville, 2001).

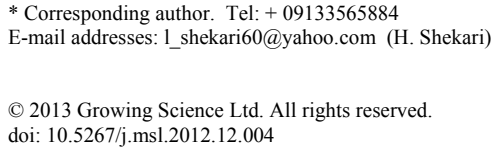


There are three assumptions associated with virtuousness, which differentiate it from other similar concepts. First, virtuousness is synonymous with the eudaemonic assumption, which assumes that an inclination exists in all human beings toward moral goodness (Dutton \& Sonenshein, 2007). The second assumption of virtuousness represents "goods of first intent' (Aristotle 1999), which means it represents inherent value. According to the third assumption of virtuousness, it creates and fosters sustainable positive energy. It elevates, self-perpetuate and requires no external motivator for its pursuit. Because it is an ultimate end and an inherent attribute of human beings, virtuousness generates an elevating impact, which is to say, virtuousness amplifies when it is experienced (Cameron, 2011).

\section{Virtuous organization}

It is not virtually possible to separate the idea of performance and well-being in organizations from the performance and well-being of their members. To provide people with meaningful work and rewards, organizations must be successful and to be successful, organizations must be highperformer. The challenge is to design organizations, which perform at high levels and treat people in ways, which motivate them, substantially (Lawler, 2004) and virtuous organization is an alternative strategy to handle such challenge (Rego et al., 2011). Virtuous organization must possess different attributes and demonstrates behaviors, which extend beyond a consistent moral or ethical code and it should possess more than just a strong values-based culture. Virtuous organizations are distinctive, in other words and they maintain capacity to create positive "organizational deviance" (Nepean, 2007). Virtuousness in organizations is associated with the behavior of individuals in organizational settings (Seligman \& Csikszentmihalyi, 2000; Snyder \& Lopez, 2002). Organizational virtuousness is associated with organizational contexts where the "good" habits, desires and actions (e.g., humanity, integrity, forgiveness, and trust) are practiced, supported, nourished, disseminated, and perpetuated, both at the individual and collective levels (Cameron et al., 2004; Rego et al., 2011). Organizational virtuousness is associated with the attributes characterizing the best of a human resource (Nepean, 2007).

Moving towards virtuousness is something most organizations can do. According to Lawler (2004), seven principles are primary keys for organizations to develop virtuousness,

1. Attraction and Retention: Organizations must create a value proposition, which describe the type of workplace they want to be so to attract and to retain the right people.

2. Hiring Practices: Organizations must hire employees who tit with their values, core competencies, and strategic goals.

3. Training and Development: Organizations must continuously train employees to do their jobs and offer them opportunities to grow and develop.

4. Work Design: Organizations must design work so that it is meaningful for people and provides them with feedback, responsibility, and autonomy.

5. Mission, Strategies, and Goals: Organizations must develop and adhere to a specific organizational mission, with strategies, objectives and values that employees can understand, support, and believe in.

6. Reward Systems: Organizations must devise and implement reward systems, which reinforce their design, core values, and strategy.

7. Leadership: Organizations must employ and develop leaders who could create commitment, trust, success, and a motivating work environment.

Effective leadership is the most important principle and the one who incorporates the glue, which holds the others together. Therefore, we should consider important points for effective leadership in Virtuous organization (Lawler, 2004) as follows,

- Lead People Right,

- Developing a Leadership Brand,

- Build Leadership Capability, 
- Identifying and Hiring Potential Leaders,

- Regular Assessment of Managerial Performance and Behavior,

- Rewards for Effective Leadership,

- Focus on the Competitive Environment.

Organizational virtuousness is not associated with an all or none condition and neither individuals nor organizations can be considered virtuous or non-virtuous. Rather, virtuousness in and through organizations can be manifested as single individuals' practical activities or as collective action, and characteristics of an organization's culture or processes, which enable or disable virtuous deeds. Three key definitional attributes are related to organizational virtuousness, which are human impact, moral goodness, and social betterment (Cameron et. al., 2003). First, virtuousness is related to human beings - with flourishing and moral character, with human strength, self-control, and resilience, and with meaningful human purpose and transcendent principles. However, desires or actions without human effects are not considered as virtuous. In addition, virtuousness is associated with moral goodness and it represents what is good, right, and worthy of development. Virtuousness possesses inherent goodness or it is desirable for its own sake. Finally, virtuousness can be characterized by social betterment and it creates social value, which transcends the instrumental desires of the actor. It generates advantages for others regardless of reciprocity or reward. Forgiveness, compassion, and courage in search of recompense, for instance, are not description of virtuous. In other words, demonstrating virtuousness is its own reward and is not oriented towards gaining external recognition, benefit, or advantage.

\section{Advantages of a virtuous organization}

The findings of investigations of the effects of virtuousness on organization and organizational performance have demonstrated substantial effectiveness and efficiency advantageous for developing and implementing of a virtue based organizational environment (Shekari et. al., 2011). The main findings are summarized as follows,

- Virtues provide interior strength for good behavior. Among human virtues, practical wisdom is particularly important. This virtue helps practical rationality identify what is good in each situation (Mele, 2009).

- Virtues provide common basis for value assimilation and value convergence of the employees (Ip, 2002).

- Virtues function as strong normative forces to shape employee's attitudes and conduct (Alzola, 2008).

- A substantially, higher level of quality decisions, information processing, team synergistic output and lower error rate due to exposure to virtuousness (Nepean, 2007).

- Virtue acts as a force, which inspire employees to incorporate a common vision. It is also a force, which motivates employees to work together under the common corporate mission as well as to develop themselves. By developing in staff a sense of responsibility, sense of honor, it helps to unleash the positive energies in employees for high performance. It also enhances employees a sense of self-respect, autonomy, and commitment (Ip, 2002).

- Virtues provide important elements of a possible riposte to the serious financial scandals currently influencing business globally (Flynn, 2008).

- Virtues make moral reasoning and moral decision-making easier, helping us to make sound ethical judgments, considering both the singularity and complexity of circumstances (Mele, 2009).

- Virtues incorporates a significantly higher level of customer loyalty and retention due to enhanced quality customer service from motivated and empowered employees due to initiation of virtuousness improvement measures (Nepean, 2007). 
- Virtues provide workers with good or very good ethical problem solving ability (Ip, 2002, p: 22).

- Virtues increase workers' satisfaction and morality in their work (Ip, 2002).

- Virtues generate positive energy in systems, increase system's growth and vitality in people, and enhance the probability of extraordinarily positive performance (Nepean, 2007).

- A substantially higher level of employees' acceptance and internalization of work place innovations; and higher level of profitability ratio because of enhanced employee innovation, expanded social capital development, increases in pro-social behavior and the development of resiliency (Nepean, 2007).

\section{Research hypotheses}

From the conceptual framework, we state research hypothesis as follows:

$\mathrm{H}_{1}$ : Care for community is positively associated with structure and processes.

$\mathrm{H}_{2}$ : Structure and processes is positively associated with virtuous organization.

$\mathrm{H}_{3}$ : Care for community is positively associated with human resource.

$\mathrm{H}_{4}$ : Human Resource is positively associated with virtuous organization.

$\mathrm{H}_{5}$ : Care for community is positively associated with organizational culture.

$\mathrm{H}_{6}$ : Care for community is positively associated with leadership.

$\mathrm{H}_{7}$ : Human Resource is positively associated with organizational culture.

$\mathrm{H}_{8}$ : Leadership is positively associated with organizational culture.

$\mathrm{H}_{9}$ : Organizational culture is positively associated with virtuous organization.

\section{Research Methodology}

The data used in this study consist of questionnaire responses from employees in Payam e Noor University in Yazd province. The questionnaire included items of leadership, organizational culture, human resource, structure and processes, care for community and virtuous organization. A total of 250 questionnaires were sent out. A total of 211 valid responses were received. Reliability of variables was evaluated by Cronbach's $\alpha$. Table 1 lists the Cronbach's $\alpha$ of the variables. As can be seen, all variables have Cronbach's $\alpha$ above 0.7 , which indicates high reliability (Nunnally, 1978)

\section{Table 1}

Cronbach's $\alpha$ of the constructs

\begin{tabular}{llllll}
\hline Variable & No. of Items & N & Means & S.D. & Cronbach's $\alpha$ \\
\hline Leadership & 13 & 211 & 4.8763 & .34952 & 0.756 \\
Organizational Culture & 14 & 211 & 4.1254 & .76385 & 0.743 \\
Human Resource & 11 & 211 & 4.2073 & .43289 & 0.804 \\
Structure and Processes & 6 & 211 & 3.7091 & .67673 & 0.771 \\
Care for Community & 14 & 211 & 4.7927 & .40574 & 0.872 \\
Virtuous Organization & 32 & 211 & 4.7509 & .32672 & 0.939 \\
\hline
\end{tabular}

\section{Structural equation modeling}

Table 2 displays the correlations of variables. As can be seen care for community and leadership are not related to each other because the Sig. of the test is more than 0.05 . Also care for community and Structure and Processes are not related to each other because the Sig. of the test is more than 0.05. But the other variables are positively related to each other. For example Care for Community is positively related to Virtuous Organization. This implies that high Care for Community can foster organizational Virtuousness. 
Table 2

Correlations of variables

\begin{tabular}{|c|c|c|c|c|c|c|c|}
\hline & Spearman's rho & Leadership & $\begin{array}{c}\text { Care for } \\
\text { Community }\end{array}$ & $\begin{array}{l}\text { Structure and } \\
\text { Processes }\end{array}$ & $\begin{array}{c}\text { Organizational } \\
\text { Culture }\end{array}$ & $\begin{array}{c}\text { Human } \\
\text { Resource }\end{array}$ & $\begin{array}{c}\text { Virtuous } \\
\text { Organization } \\
\end{array}$ \\
\hline \multirow{3}{*}{ Leadership } & Correlation Coefficient & 1.000 & .109 & .278 & $.738^{* *}$ & $.421^{\text {*.7 }}$ & $.592^{* 7}$ \\
\hline & Sig. (2-tailed) & . & .059 & .000 & .000 & .000 & .000 \\
\hline & $\mathrm{N}$ & 211 & 574 & 211 & 211 & 211 & 211 \\
\hline \multirow{3}{*}{$\begin{array}{l}\text { Care for } \\
\text { Community }\end{array}$} & Correlation Coefficient & .109 & 1.000 & .243 & $.430^{* *}$ & $.574^{* *}$ & $.697^{* *}$ \\
\hline & Sig. (2-tailed) & .059 & . & .058 & .000 & .000 & .000 \\
\hline & $\mathrm{N}$ & 574 & 211 & 211 & 211 & 211 & 211 \\
\hline \multirow{3}{*}{$\begin{array}{l}\text { Structure and } \\
\text { Processes }\end{array}$} & Correlation Coefficient & .278 & .243 & 1.000 & $.095^{* *}$ & .101 & $.373^{* *}$ \\
\hline & Sig. (2-tailed) & .000 & .058 & . & .000 & .008 & .000 \\
\hline & $\mathrm{N}$ & 211 & 211 & 211 & 211 & 211 & 211 \\
\hline \multirow{3}{*}{$\begin{array}{l}\text { Organizational } \\
\text { Culture }\end{array}$} & Correlation Coefficient & $.738^{* *}$ & $.430^{* *}$ & $.095^{* *}$ & 1.000 & $.283^{* *}$ & $.801^{* *}$ \\
\hline & Sig. (2-tailed) & .000 & .000 & .000 & . & .000 & .000 \\
\hline & $\mathrm{N}$ & 211 & 211 & 211 & 211 & 211 & 211 \\
\hline \multirow{3}{*}{$\begin{array}{l}\text { Human } \\
\text { Resource }\end{array}$} & Correlation Coefficient & $.421^{* *}$ & $.574^{* *}$ & .101 & $.283^{* *}$ & 1.000 & $.844^{* *}$ \\
\hline & Sig. (2-tailed) & .000 & .000 & .008 & .000 & . & .000 \\
\hline & $\mathrm{N}$ & 211 & 211 & 211 & 211 & 211 & 211 \\
\hline \multirow{3}{*}{$\begin{array}{l}\text { Virtuous } \\
\text { Organization }\end{array}$} & Correlation Coefficient & $.592^{* *}$ & $.697^{* *}$ & $.373^{* *}$ & $.801^{* *}$ & $.844^{* *}$ & 1.000 \\
\hline & Sig. (2-tailed) & .000 & .000 & .000 & .000 & .000 & . \\
\hline & $\mathrm{N}$ & 211 & 211 & 211 & 211 & 211 & 211 \\
\hline
\end{tabular}

Correlations can only reveal the degree of relationship between constructs. To further investigate the direct and indirect effects, as well as the mediating effects among the constructs, structural equation modeling was performed using LISREL. Fig. 1 shows the Path diagram of the completely mediating model and Fig. 2 shows the T-values of path diagram. The model estimation results reveal the following relationships among research variables:

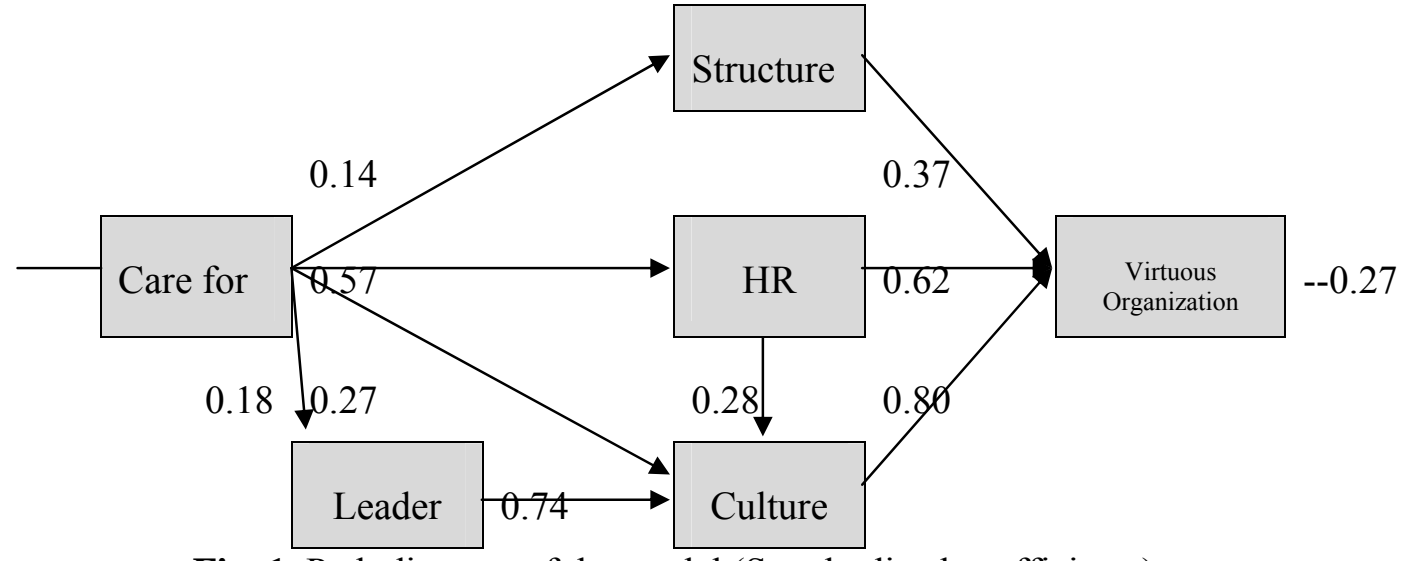

Fig. 1. Path diagram of the model (Standardized coefficients)

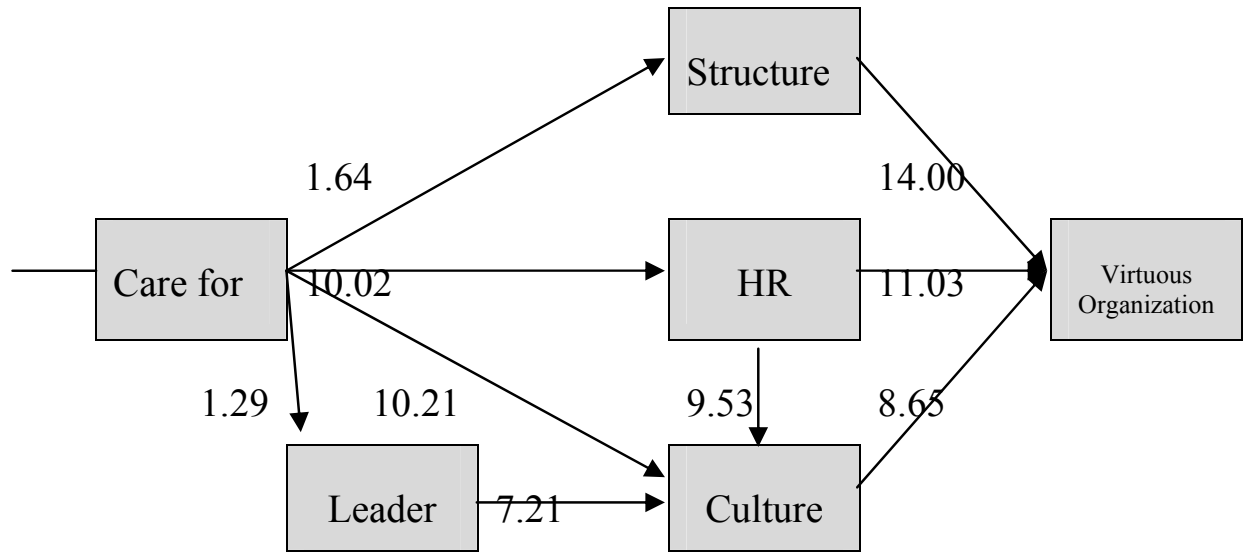

Fig. 2. T-values of path diagram (Unstandardized coefficients) 
Relationship between care for community and structure and processes is not statistically significant since the t-value of this estimate is less than 2 (Liao et. al., 2008). This indicates that care for community does not have any impact on structure and processes. Hence, $\mathrm{H}_{1}$ is not supported. Similarly, relationship between care for community and Leadership is not significant, which indicates that care for community does not have an impact on Leadership and $\mathrm{H}_{6}$ is not supported. Relationships between other variables are positive and significant. Therefore, the other hypotheses are all supported.

Table 3 summarizes the results of hypotheses. For example, the relationship between organizational culture and virtuous organization is positive and significant and this indicates that organizational culture does have a positive impact on virtuous organization. In other words, higher organizational culture will lead to better performance in organizational virtuousness and we can conclude that $\mathrm{H}_{9}$ is supported.

\section{Table 3}

Results of the research hypotheses

\begin{tabular}{|c|c|c|c|c|}
\hline Paths/hypotheses & $\begin{array}{c}\text { Path } \\
\text { coefficients }\end{array}$ & t-value & $\begin{array}{l}\text { Hypothesized } \\
\text { relationship }\end{array}$ & Result \\
\hline Care for Community $\rightarrow$ Structure and Processes & 0.14 & 1.64 & Positive & Not supported \\
\hline $\begin{array}{l}\text { Structure and Processes } \rightarrow \text { Virtuous } \\
\text { Organization }\end{array}$ & 0.37 & 14.00 & Positive & supported \\
\hline Care for Community $\rightarrow$ Human Resource & 0.57 & 10.02 & Positive & supported \\
\hline Human Resource $\rightarrow$ Virtuous Organization & 0.62 & 11.03 & Positive & supported \\
\hline Care for Community $\rightarrow$ Organizational Culture & 0.27 & 10.21 & Positive & supported \\
\hline Care for Community $\rightarrow$ Leadership & 0.18 & 1.29 & Positive & Not supported \\
\hline Human Resource $\rightarrow$ Organizational Culture & 0.28 & 9.53 & Positive & supported \\
\hline Leadership $\rightarrow$ Organizational Culture & 0.74 & 7.21 & Positive & supported \\
\hline $\begin{array}{l}\text { Organizational Culture } \rightarrow \text { Virtuous } \\
\text { Organization }\end{array}$ & 0.80 & 8.65 & Positive & supported \\
\hline$\chi 2_{/ \mathrm{df}}=2.70 \quad \mathrm{GFI}=0.96$ & $\mathrm{NNFI}=$ & & RMSI & $=0.06$ \\
\hline
\end{tabular}

Table 4 shows effects of variables on virtuous organization and Table 5 shows indirect effects of variables on virtuous organization

Table 4

Effects of variables on virtuous organization

\begin{tabular}{lccc}
\hline Variable & Direct effect & Indirect effect & Total effect \\
\hline Leadership & --- & 0.592 & 0.592 \\
Organizational Culture & 0.80 & --- & 0.80 \\
Human Resource & 0.62 & 0.224 & 0.844 \\
Structure and Processes & 0.37 & --- & 0.37 \\
Care for Community & --- & 0.697 & 0.697 \\
\hline
\end{tabular}

Table 5

Indirect effects of variables on virtuous organization

\begin{tabular}{lcccc}
\hline Construct & $\begin{array}{c}\text { Through } \\
\text { Organizational Culture }\end{array}$ & $\begin{array}{c}\text { Through } \\
\text { Human Resource }\end{array}$ & $\begin{array}{c}\text { Through } \\
\text { HR and Culture }\end{array}$ & $\begin{array}{c}\text { Total Indirect } \\
\text { effect }\end{array}$ \\
\hline Leadership & 0.592 & --- & --- & 0.592 \\
Human Resource & 0.224 & --- & --- & 0.224 \\
Care for Community & 0.216 & 0.353 & 0.128 & 0.697 \\
\hline
\end{tabular}


As seen in Table 4 and Table 5, the direct effects of organizational culture, human resource, structure, and processes on virtuous organization are more significant than indirect effects do; but for leadership and care for community, the indirect effects are more significant than direct effects are.

\section{Discussion and conclusion}

In this paper, we have investigated the effects of five variables including leadership, organizational culture, human resource, structure and processes and care for community on the virtuous organization. Among these variables, organizational culture has the highest direct impact on virtuous organization implying that improving the measurement items of organizational culture will lead to better performance in organizational virtuousness. This has important implications for managers striving for organizational virtuousness. That is, from the point of view of organizational culture, if managers want to make their organizations virtuous, they have to:

- Promote Ethics

- Consider employees as competitive advantages for organization

- Not only concentrate on profit maximization

- Go beyond ethics

- Provide ethical standards for employee's and manager's behavior

- Share information in organization

- Pay attention to employee's development more than their training

- Consider employee's competencies

- Combine high standards of performance with a culture of forgiveness and learning from mistakes

Among the five variables, care for community has the most indirect impact on virtuous organization implying that improving the measurement items of care for community will indirectly (through organizational culture and human resource) lead to better performance in organizational virtuousness. This has important implications for managers striving for organizational virtuousness. That is, if managers want to move toward virtuous organization, they have to consider following points:

- Corporate Philanthropy

- Respecting the social laws

- Avoiding harming others

- Respecting the rights of others

- Respecting the social values

- Allotting a special budget to help the homeless find job and housing

- Hiring the Disabled

- Considering virtues in the culture of community

- Helping those in need

- Concerning about the Environment and the community

- Concerning about the Local suppliers

- Behaving in a socially responsible and environmentally sensitive manner

Among the five variables, human resource has the most total impact (0.844) on virtuous organization. Of this total impact, the size 0.62 is direct. Therefore, the measurement items of human resource can directly increase virtuousness in organization. That is, from the point of view of human resource, if managers want to make their organizations virtuous, they have to consider these points in their employees:

- Employees' faithfulness

- Employees' readiness from the point of view of individual characteristics, motives, internal tendency, etc.

- Interpersonal relationships characterized by caring and compassion 
- Employees' perception of virtuousness in organization

- Penetrating virtues in employee's feelings, thinking and actions

- Employees' stability in difficulties and crises

- Employees' self-control

\section{References}

Alzola, M. (2008). Character and environment: The status of virtues in organizations. Journal of Business Ethics, 78, 343-357.

Aristotle. (1999). Nicomachean ethics (M. Oswald, Trans.). Upper Saddle River NJ: Prentice Hall.

Cameron, K. (2003). Organizational virtuousness and performance, In Positive Organizational Scholarship. KS Cameron, JE Dutton and RE Quinn (eds.), San Francisco: Berrett-Koehler.

Cameron, K. S. (2011). Responsible leadership as virtuous leadership. Journal of Business Ethics, 98, 25-35.

Cameron, K. S., Bright, D., \& Caza, A. (2004). Exploring the relationships between organizational virtuousness and performance. American Beharioral scientist, 47, 766-790.

Cameron, K. S., \& Winn, B. (2012). Virtuousness in organizations. In K. S. Cameron and G. M. Spreitzer (Eds.). Oxford handbook of positive organizational scholarship, New York: Oxford University Press.

Comte-Sponville, A. (2001). A small treatise of the great virtues. New York: Metropolitan Books.

Dutton, J. E., \& Sonenshein, S. (2007). Positive organizational scholarship. In S. Lopez \& A. Beauchamps (Eds.), Encyclopedia of positive psychology. Malden, MA: Blackwell Publishing.

Flynn, G. (2008). The virtuous manager: A vision for leadership in business. Journal of Business Ethics, 78, 359-372.

Ip, P.K. (2002). The weizhi group of xian: A Chinese virtuous corporation. Journal of Business Ethics, 35, 15-26

Lawler, E. E. (2004). Leading a virtuous - spiral organization. Leader to leader, 32, spring.

Liao, S.H., Fei, W.C., \& Liu, C.T. (2008). Relationships between knowledge inertia, organizational learning and organization innovation. Technovation, 28, 183-195.

Mele, D. (2009). Integrating persona list into virtue- based Business ethics: the persona list and the common good businciples. Journal of Business ethics, 88, 227-244.

Nepean, W. (2007). Virtuous Firms Perform Better: An Empirical Investigation of Organizational Virtues and Performance. Business Post Comment

Nunnally, J.C. (1978). Psychometric Theory. $2^{\text {nd }}$ ed., McGraw-Hill, New York.

Rego, Armenio, Ribeiro, Neuza, Cunha, Miguel Pina e and Jesuino, Jorge correia (2011). How Happiness Mediates the Organizational Virtuousness and Effective Commitment Relation Ship. Journal of Business Research 64, 524-532.

Seligman, M. E. P., \& Csikszentmihalyi, M. (2000). Positive psychology: an introduction. American Psychologist, 55, 5-14.

Shekari, H., Afshari, M.A., \& Veyseh, S.M. (2011). Developing values in organization: a reflection on organizational virtuousness approach. International Journal of Research in Commerce and Management, 2(5), 11-15.

Snyder, C. R., \& Lopez, S. J. (2002). Handbook of Positive Psychology. New York, Oxford University Press. 